\title{
Community Perception on Preparation of Brebes District's Expansion
}

\author{
${ }^{1}$ EPPY YULIANI, ${ }^{2}$ ARDIANA YULI PUSPITASARI, ${ }^{3}$ SHABRINA AYU ARDINI \\ 123 Program Studi Perencanaan Wilayah dan Kota, Universitas Islam Sultan Agung Semarang, \\ Jl. Raya Kaligawe km 4 Semarang \\ email: ${ }^{1}$ epp.yul@gmail.com; ${ }^{2}$ ardiana@gmail.com; ${ }^{3}$ shabrinaayu9@gmail.com
}

\begin{abstract}
Brebes Regency is the largest area in Central Java Province with the southern region distance where central government situated to northern region of $\pm 55 \mathrm{Km}$. Such condition affects public services. It reinforces the emergence of territorial expansion issue in Brebes Regency, particularly in region of South Brebes. The territorial expansion that may apply to Brebes Regency, based on Government Regulation No. 78 year of 2007, is a formation since the objective to be achieved is granting a new status to South Brebes region as a regency. The purpose of this study is to analyze the perception of community towards the preparation of regional expansion in Brebes Regency. This research uses a rationalistic quantitative descriptive approach method with four variables to measure public perception, namely attention, experience, mindset, and expectation. The conclusion of the research on the attention factor, mindset, and needs of community perception is very good. The territorial expansion is expected to improve public services and welfare. While the perception of experience factor is less good, due to lack of socialization.
\end{abstract}

Keywords: Expansion, perception, community.

\section{Introduction}

Territorial expansion is carried out to achieve the optimization of government implementation and facilitate public service in new autonomous regions. One of the benefits of regional expansion is the formation of new autonomous region that is expected to increase the efficiency and effectiveness of local governments in providing public services to the community, which ultimately would prosper the community in the expansion area.

Brebes Regency is the largest regency in Central Java after Cilacap. It has a landscape of hills and beaches, as well as two different cultures, namely Java and Sunda. Brebes district is a developing district whose location is surrounded by large urban areas such as Cirebon, Tegal, Purwokerto. Such condition reinforces the emergence of territorial expansion issue in Brebes Regency, precisely in region of South Brebes. The territorial expansion that may apply to Brebes Regency, based on Government Regulation No. 78 year of 2007, is a formation of New Autonomous Region since the objective to be achieved is granting a new status to South Brebes region as a regency. The latest research related to the feasibility of the expansion of Brebes Regency was conducted by Brebes District Government in 2015. The results obtained from the research were "requirements of expansion", focusing on scoring each indicator of expansion. Nevertheless, the research conducted by Brebes District Government was only used 2 out of 3 requirements of expansion stipulated in Government Regulation Number 78 Year 2007 regarding Procedures for Formation, Elimination and Regional Merger. Whereas there are 3 basic requirements for the establishment of a New Autonomous Region, namely technical, physical, and administrative requirements.

The feasibility and success of the expansion of the region is not only about the technical and physical aspects of the territory, but also take into consideration the opinions or aspirations of the affected people as the goal of expansion. Therefore, community aspirations need to be explored through the analysis of public perceptions on the feasibility of Brebes Regency expansion. Most of the time, planning process occurred in Brebes Regency was only involved the

Received: December 07, 2017, Revision: March 27, 2018, Accepted: June 09, 2018

Print ISSN: 0215-8175; Online ISSN: 2303-2499. DOI: http://dx.doi.org/10.29313/mimbar.v34i1.3264.224-236

Accredited B based on the decree No.040/P/2014, valid on February, 18, 2014 until February, 18, 2019. Indexed by DOAJ, Sinta, IPI 
community as a listener in the socialization activities of territorial expansion. Based on the theory of Arnstein, peoples participation in South Brebes is only at level 2, namely level of therapy. Local Government should more involve the community in planning, so that the plan of Brebes Regency expansion can be in accordance to society requirement, which also improving the prosperity and public service in New Autonomous Region (NAR).

The problem occurred today is that the southern Brebes region has a distance of $+55 \mathrm{~km}$ to the central government of Brebes Regency, so that people have difficulties in obtaining public services. Consequently, the community proposed the expansion of the region into South Brebes Regency.

The purpose of this study is to analyze the perception of the community towards the readiness of regional expansion in Brebes Regency. Targets prepared to achieve the objectives are: (a) Identification of the South Brebes region; (b) Identification of population of South Brebes region; (c) To analyze the readiness of Brebes Regency expansion plan. (d) To analyze people's perception on the readiness of the expansion of Brebes regency.

Regional development is carried out in accordance with the principles of autonomy and decentralization. Local governments have full authority to develop regional economic management institutions, their human resources, a business climate that can attract capital and investment, and the active role of the private sector and community through ongoing coordination with all development stakeholders both at regional and central levels. Local Government acts as facilitator and catalyst for the growing interest of investment in the region (Yana Tatiana, et al MIMBAR, Vol. 31, No. 2 (December, 2015): 295-306).

Perception is an attempt to recognize objects or information through the process of observing, understanding, or interpreting the stimuli received by the senses (Maramis, 1999 in Sunaryo, 2004: 94). Another definition of perception is the experience of an object, event, or relationships obtained through a sensory stimulus (Rakhmat 1990: 51). The perception formed is done by deducing information and interpreting the message. Desiderato (in Supratman and Adi, 2016: 45) has similar definition on perception, i.e an experience of objects or stimuli by a person through sensing, then summed up into an information and interpretation of the message. Richard S. Crutchfield describes related factors that can influence a person's perception in the environment or society (Supratman and Adi, 2016: 72). First, functional factors, derived from the needs, experience, motivation, the process of formation of impression, and personality or individual characteristics. Second, structural factors, derived from the nature of the physical stimulus and the nerves inflicted by the individual. While the important factors that affect perceptions according to Kenneth is attention. Attention is very influential on the emergence of perception in a person (Rakhmat, 1990: 52). Whether a person is interested in an object or a stimulus is influenced by 2 factors, namely internal factors derived from the habits, interests, emotions, and biological state of a person upon receiving the stimulus; and external factors derived from the intensity, movement, and repetition of the stimulus. In addition to the above factors, Krech and Crutchfield (in Rakhmat, 1990: 56) explain the formation of a person's perceptions influenced by several factors, namely: attention as the focus of individual towards the object; mindset defines as an individual mindset in receiving stimulus; need comes from the impulse in a person related to the object, such as desire, demands, ideals, and so forth; the value system as a system of social values and norms that applied; and personality $s$ an individual characteristic, such as educational background, religion, age, gender, culture, and social stratification in society.

Territorial expansion is an effort to establish a new autonomous region through 3 forms, namely split-off, enlarging, and amalgamation (Sjafrizal, 2008: 266). Separation is an attempt of regional expansion from old administrative area into a new one. Expansion usually occurs in urban areas whose development has expanded into rural areas, thus affecting the structure of space and its economy. While unification is a merger of two or more old administrative areas into a new administrative region within a single governance system. Each form of regional arrangement has different objectives, considerations, and impacts on the relevant regional development process. Expansion of the region by Nainggolan (in Silitonga, 2000: 90 ) is the process of expansion and merging of the region in an effort to strengthen the relationship between the community and the new autonomous regional government. An expansion would create more effective 
interaction because local government can find out the aspirations and needs of the community, so that public services can be done optimally and lead to the improvement of community's welfare. Another opinion related to regional expansion is the effort to optimize the governance implementation, and regional development can be pursued through the expansion of the region (Syarbaini, 2014: 177).

Each region has different conditions that can trigger the expansion. Existing conditions can come from the demands of people who have different ethno demographic and politic (Tirtosudarmo, 2007: 140). Ethno demographic derived from heterogeneous society conditions in an area consist of groups of people with ethnic, cultural, religious, and other differences that can trigger disagreements or disputes. Apart from condition of society, political factors also become the basis for groups formation that bring interests in the development of a region. Sjafrizal also conveyed other trigger factors of regional expansion, among others are religion differences factor, ethnic and cultural differences, economic growth disparities between regions, and the size of the area (Sjafrizal, 2008).

According to researcher, in a region which has large area, and considering the ethno demographic condition, that region needs an expansion in order to gain equality of economic growth, bring public service closer to the community, and maintain the security of the region. Consequently, the government establishes new government agencies and institutions. This certainly has an impact on the increase of local budgets.

According to Smith (in Dharma Setyawan Salam, 2004: 108), the success of the implementation of regional autonomy lies in the functions or duties of government, the ability to collect local taxes, administrative duties, the amount of authority delegation, the size of budget, region, financial dependency, and personnel. Furthermore, the affairs which can be a Household Regional's have been naturally attached to the region, in which fostering community participation, concerning the direct interest of the community to include a lot of human resources, supplement the local income and requires the handling of state decision making (B. Hestu Cipto Handoyo, 1998; 7-8) in Achmad Surkati, MIMBAR, Vol. XXVIII, No. 1 (June, 2012): 39-46.

\section{Methodology}

The approach used in this research is rationalistic quantitative descriptive method. Descriptive research is a research for factfinding with appropriate interpretation (Whitney in Nazir, 1999: 63). The methodology of quantitative is used in research that aims to find causal relationships, correlations, and evaluations of objective activities or programs (Semiawan, 2010: 67). The rationalistic approach is a science derived from an intellectual understanding built on logical argumentation and supported by relevant empirical data (Muhadjir, 1991: 83). Data collection techniques in this research related to the study of the readiness of Brebes District expansion based on the perception of the community using 4 techniques, namely document review, field observation, questionnaires, and interviews with the Head of District in Southern Brebes and Brebes Regency. Sampling questionnaire used is Slovin formula with $90 \%$ of confidence level (e $=10 \%$ ), considering the smaller percentage of inaccuracy loosening in sampling would make the samples added in number and become more representative. There were 100 respondents from Slovin calculations, with the criteria of population of 15-59 years old as many as 290,360 people in South Brebes. Analysis technique used is percentage descriptive analysis technique. The purpose of this technique is to explore the tendency of public perception in each variable. Each variable has 5 classifications to be chosen by the respondent in accordance with the facts experienced. Descriptive calculation percentage for 5 classification resulted in interval class in Table 1.

Table 1

Percentage Interpretation

\begin{tabular}{|ll|}
\hline Value Interval \% & Classification \\
\hline $581-100$ & Strongly agree \\
$461-80$ & Agree \\
$341-60$ & Simply agree \\
$221-40$ & Less agree \\
$10-20$ & Disagree \\
\hline
\end{tabular}

Source: Analysis Result, 2017

Percentage interval table is used in assisting analysis of each research variable. Seeing the tendency of public perception towards the regional expansion calculated through the average classification with the following formula (Sudjana, 2009: 129) 
Setting the highest percentage value is $100 \%$ and the lowest is $0 \%$;

Setting a Value Range

Value Range $=$ Highest - Lowest

$=100 \%-0 \%=100 \%$

Specifies the Class Interval

\section{Class Interval = Value Range Number of Classes $=\frac{100 \%}{5}=20 \%$ \\ Determining Average Classification Average Classification $=\Sigma[$ Frek @classification* Classification Value $]$ $\Sigma$ Responden}

\section{Southern Brebes Administrative Region}

Southern Brebes according to Regional Regulation No. 2 of 2011 on RTRW of Brebes Regency, consists of 6 sub-districts, namely District of Salem, Bantarkawung, Bumiayu, Paguyangan, Sirampog, and Tonjong. Brebes Regency has coordinates of $108^{\circ} 41^{\prime} 37,7^{\prime \prime}-109^{\circ} 11^{\prime} 28,92^{\prime \prime}$ East Longitude and $6^{\circ} 44^{\prime} 56^{\prime} 5^{\prime \prime}-7^{\circ} 20^{\prime} 51,48$ South latitude. Southern Brebes has an area of 68,401 ha with the administrative location as follows (see Map 3. 4).

North: Brebes Tengah (middle); East: Tegal Regency and Tegal city; South: Banyumas and Cilacap Regency; West side: West Java Province.

Population of South Brebes in 2015 was 475,846 inhabitants consisting of 236,017 male and 239,829 female. Based on the population of each sub-district, the largest population is in Paguyangan sub-district with 99.847 people and the lowest is in Salem sub-district with 59,288 people (Kabupaten Brebes dalam Angka/Brebes Regency in
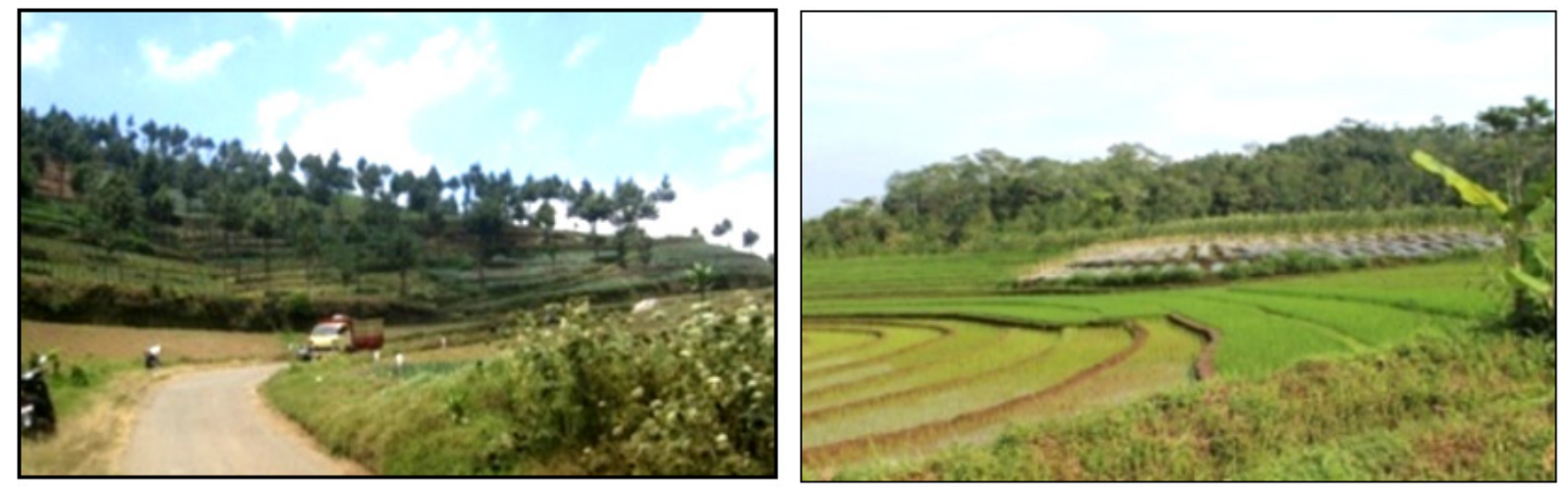

Source: Field Survey Results, 2017

Number, 2016)

South Brebes has a landscape of hilly area at the foot of Mount Slamet. Rainfall is in the medium classification or 2,5003,500 $\mathrm{mm} /$ year. Such condition make the South Brebes region has a potential to be horticultural vegetables producer.

Southern Brebes region has 5 topography classifications or soil slope spread over 6 districts in South Brebes. Here is the distribution in each sub-district:

Sub-district Salem: does not have topography with a ramps classification. it is dominated by soil slope with classification of $15 \%-25 \%$ and followed by the classification of $8 \%-15 \%$. Despite the small avalanche potential, the Salem sub-district functions are categorized as the buffer zone.

Bantarkawung Sub-district: has 5 topographic classifications, but dominated by the soil slope at the classification of $15 \%$ $-25 \%$. With a fairly steep slope of land, Bantarkawung has a small avalanche potential and the function of the cultivation area is still quite wide;

Bumiayu Sub-district: dominated slope of $0 \%-8 \%$ land or classification of ramps. The classification makes Bumiayu has the most extensive cultivation area function compared to other districts in South Brebes. According to the Regional Regulation of Brebes Regency, Bumiayu Sub-district is designated as PKL (Local Activity Center) such as settlement and service trade.

Paguyangan Sub-district: has 5 topographic classification but dominated by land slope $25 \%-40 \%$ and followed by slope 15\% - 25\% (Kabupaten Brebes dalam Angka/ Brebes Regency in Number, 2016).

Bantarkawung Sub-district has landslide

Figure 1. Geographical Condition of South Brebes 
potential because it is dominated by soil slope classification of steep enough to steep, so the function of the area is more to buffer zone;

Sirampog Sub-district: has 5 topographic classifications, but dominated by the slope of soil in the classification of $25 \%-40 \%$. Sirampog Sub-district with steep slopes has landslide potential, so that the function of the area is dominated as buffer zone and a small part of protection function;

Tonjong Sub-district: dominated by $0 \%-8 \%$ soil slope or slope classification. The classification makes Tonjong District has a wide area of cultivation function such as Bumiayu and the landslide potential is quite small.

\section{Potency}

South Brebes is in the hilly region of Mount Slamet with a fertile soil condition which make it has a lot of natural resources potential for agriculture. South Brebes rice harvest area reaches 41,169 ha/year. South Brebes has a great potential of horticultural crops producer of potatoes with production of 55,187 tons/year, cabbage 35,889 tons/year, carrots 16,142 tons/year, chili 371 tons/ year, red onion 1.676 tons/year, and petai 443 tons/year. In addition to horticultural crops, South Brebes region also has the potential of fruit production, namely rambutan for 1.409 tons/year and durian for 394 tons/ year. (Kabupaten Brebes/Brebes Regent in Numbers, 2016)

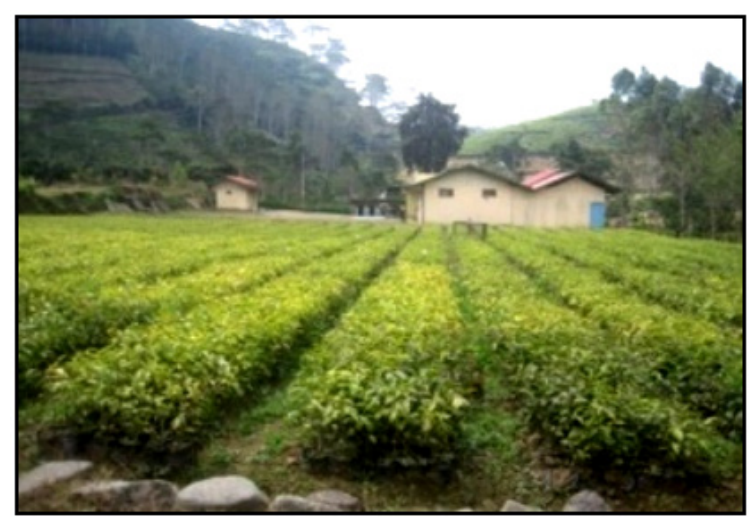

Source: Field Survey Results, 2017

Figure 2 Potential of South Brebes Plantation and Rice Field

In addition to the potential already mentioned, South Brebes region in the form of hills is also widely used as a natural tourist attraction. Its nature tourism is in the form of waters and plantations that have been

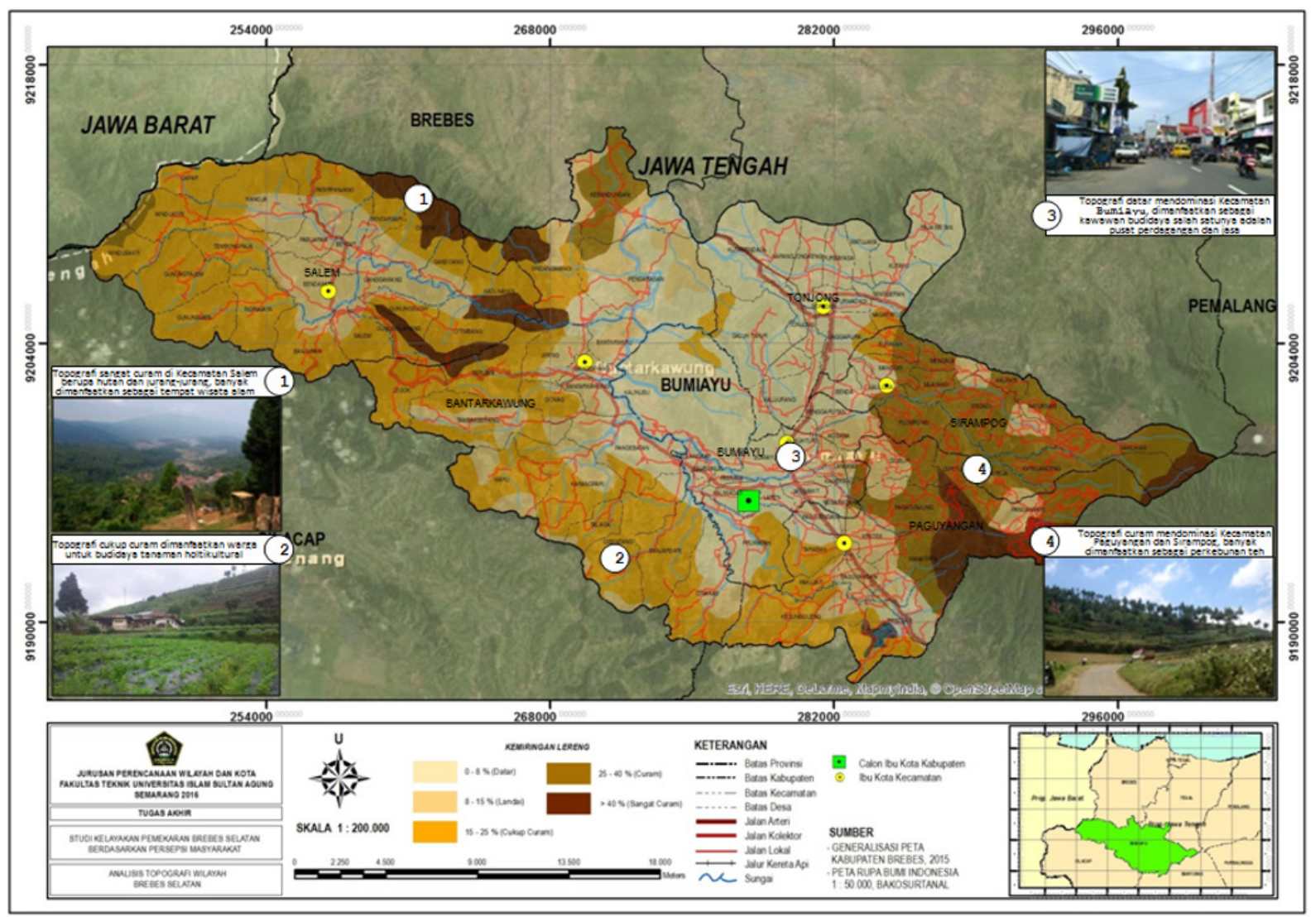

Source: RTRW Kabupaten Brebes 2011-2030 and Analysis Result 2017

Map 1. Analysis of Topographic Condition in Southern Brebes 


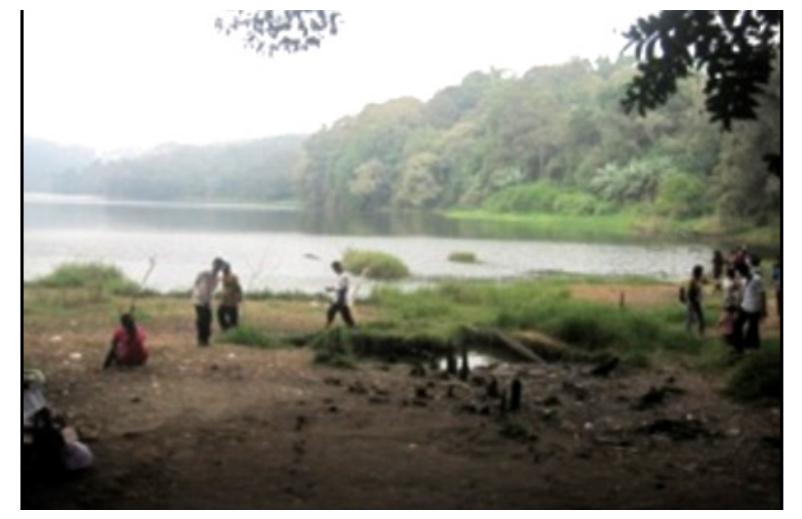

Figure 3. Natural Tourism Potential of South Brebes
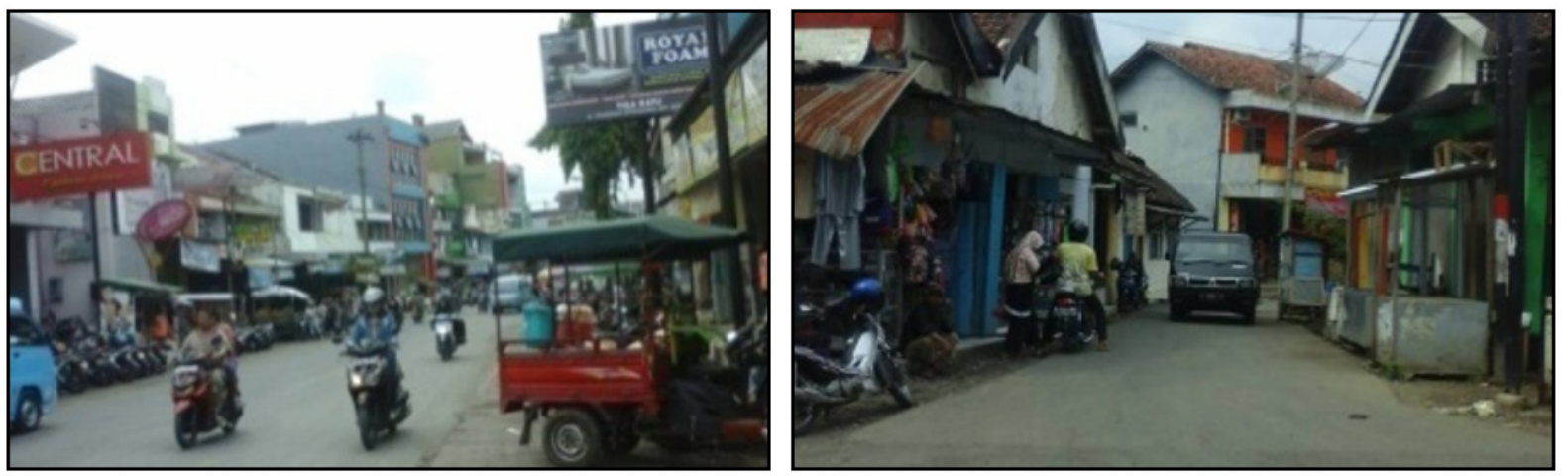

Source: Field Survey Results, 2017

Figure 4. Accessibility of South Brebes

managed by the government, private, and community. One of the natural attractions of the waters is the Natural Reserve of Telaga Ranjeng located in Paguyangan Sub-district. Ranjeng Lake Nature Reserve offers a beautiful mountain atmosphere and is a habitat of catfish and indigo. Not far from Telaga Ranjeng, there is agro-tourism Kaligua Tea Garden which is managed by PT. Perkebunan Nusantara IX (Persero). Kaligua Tea Garden Tour is a famous tourist attraction in the South Brebes region with the number of visitors reached 129,467 people per year (PTP IX, 2016). In addition to presenting a vast tea plantation, an agro-tourism is also provide other supporting facilities such as lodging, Goa Japan (Japan Cave), Tuk Bening Springs, and outbound area. The potential of nature in the form of agriculture and tourism are quite diverse. The existence of such natural potential, if it is developed and managed professionally can increase local revenue, especially for South Brebes region when it has officially become a new autonomous region.

\section{Accessibility}

South Brebes region has a road classification of national road (arterial road). Connecting between North Coast Path (Pantura) of Brebes Regency with South Line or Banyumas Regency. The distance from Bumiayu Sub-district to Brebes service center is $\pm 55 \mathrm{Km}$, which is further than to the Purwokerto Urban Service Center which is only $\pm 38 \mathrm{Km}$. South Brebes region also passed the provincial road (collector road), in the form of South Lingkar Road that serves to break the congestion in urban area of Bumiayu.

The existence of the classification of arterial and collector roads makes the mobility in the South Brebes region is quite crowded. Therefore, the community takes benefit upon that situation by opening trade and service business along the main road. In Bumiayu Sub-district there is also Bus Terminal of B type which serves intercity bus and bus transportation within the province, and buses that serve big cities outside Central Java Province, such as buses to Bandung and Jakarta. There are also district roads (local roads) and other roads in form of environmental roads and trails. In addition to public roads, the South Brebes region is also bypassed by the Indonesian Railway 


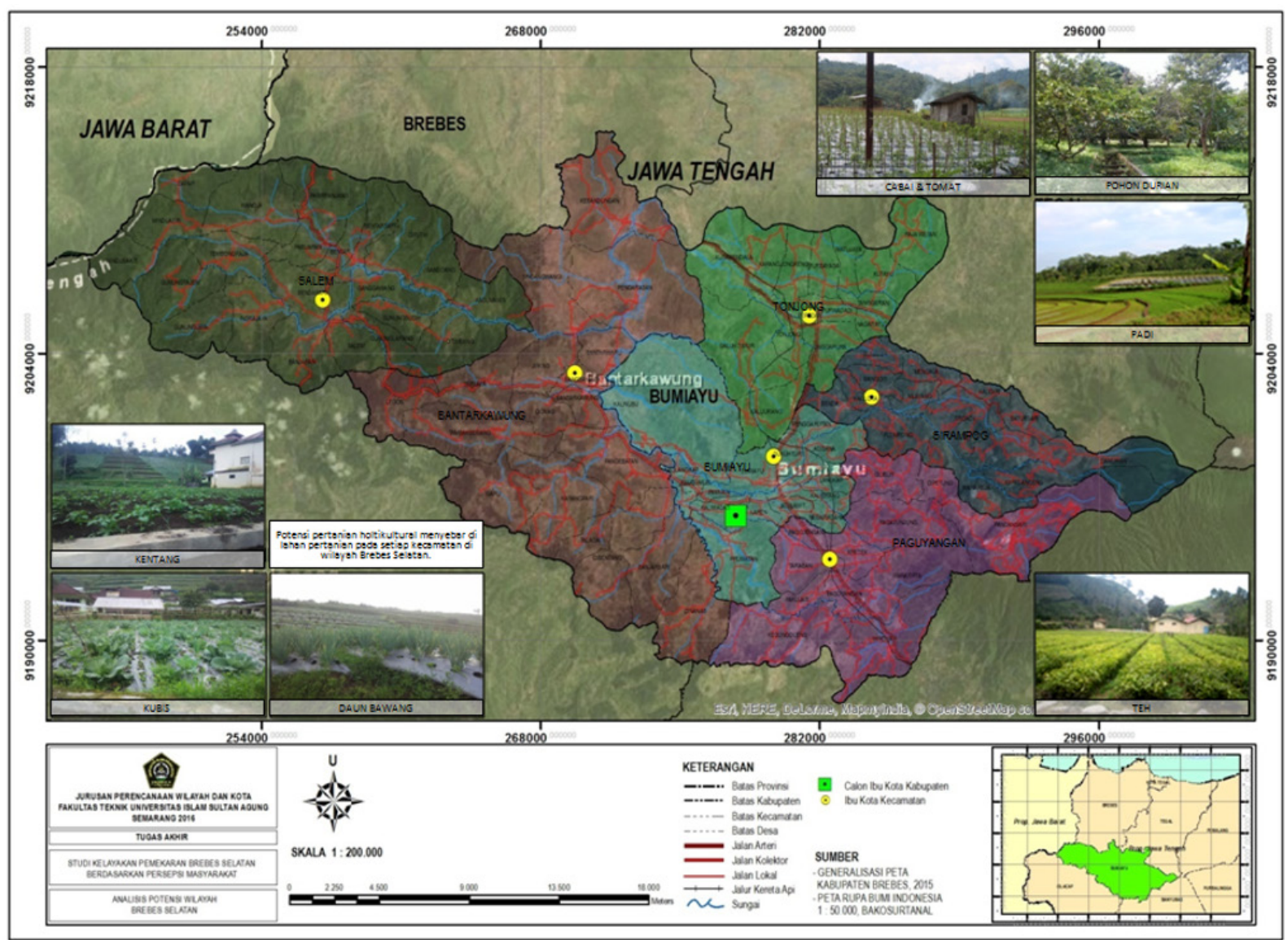

Source: RTRW Kabupaten Brebes 2011-2030 and Analysis Result 2017 Map 2. Analysis of Agricultural Potential of South Brebes

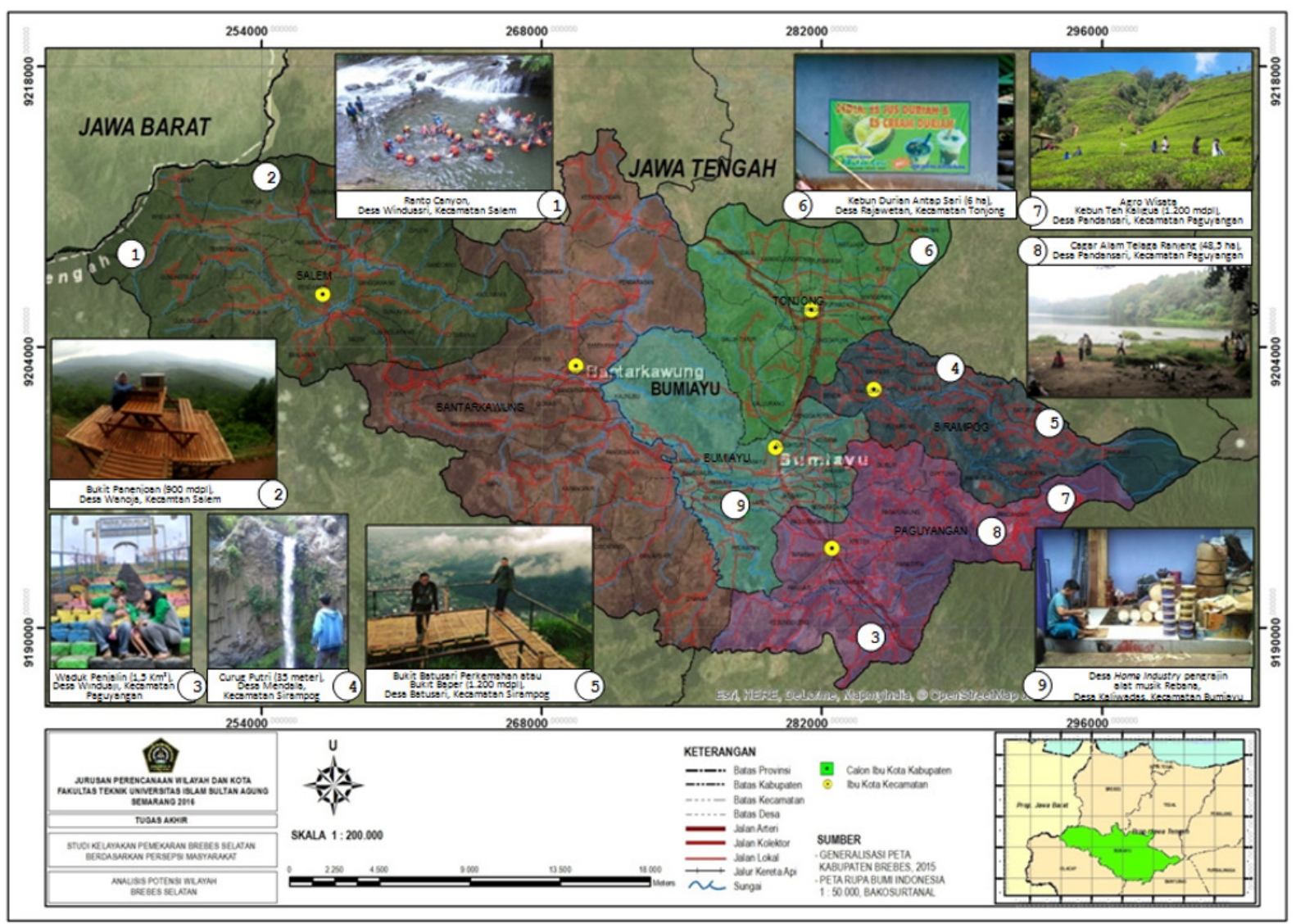

Source: RTRW Kabupaten Brebes 2011-2030 and Analysis Result 2017 Map 3. Analysis of Tourism Potential in South Brebes 
line with stations located in Bumiayu Subdistrict. Bumiayu Station (BMA) is a class II station belongs to the Operational Area (Daop) V Purwokerto. Bumiayu Station has a business class and economy train to Jakarta, Semarang, and Jogja-Solo. Bumiayu Station is a stopover station, not a departure station or station of final destination.

\section{Analysis of Readiness of Brebes Regency expansion}

The technical requirements of the new autonomous regions based on the guidance of PP 78 of 2007 include: population, economic capacity, regional potential, financial capacity, socio-cultural, socio-political, area, defense, security, welfare level, and span of control.

The number of South Brebes NAR candidates is 475,648 people or $49.29 \%$ of the total population of Regency in Central Java Province which is 964,975 people per Regency. While the density of the population of South Brebes NAR candidates as much as 642 or $62.02 \%$ of the average population density of the Regency in Central Java Province which is 1034.34 . Population factors have a total score of 65 from a maximum score of 100 or can be said to be quite appropriate.

Economic ability. The average non-oil/ gas per capita per district in Central Java reaches $11,728,928,57$, while in the candidate new autonomous region only 4,551.115,25. This means that the amount of non-oil/gas per capita GRDP in prospective NAR reaches only $38.80 \%$. For the average economic growth of Central Java District reached $5.47 \%$ while in the NAR candidates only $4.2 \%$. This means that the amount of economic growth in prospective NAR reaches only $76.89 \%$. As for the total contribution of non-oil and gas GRDP in Central Java reached 4,694,748.60, whereas in the new NAR candidates only $2,183,670.05$. This means that the total contribution of non-oil and gas GRDP in prospective new autonomous regions only reached $46.51 \%$. According to research that have been done, economic ability factor has a total score of 45 from a maximum score of 100 or can be quite appropriate (Local Government Research Results Brebes, 2015).

Regional potential is the approximate acceptance of the planned utilization of the availability of artificial resources, apparatus resources, and community resources that will be used to improve public services. The comparison of human resource value of senior high school (SMA) level in candidate of NAR with average Regency of Central Java reach $79,86 \%$. The ratio of SMA per high school age population in prospective NAR is $0.0005 \%$, while in the mean value of Central Java District is $0,0017 \%$. Thus, the percentage ratio of SMA per high school age population is $28.73 \%$.

Financial Capacity Factor: the assessment of technical requirements in the expansion of regions has a ratio of $1.73 \%$ percentage for new autonomous regions and $1.50 \%$ for districts throughout Central Java. The PDS (Own Revenue) Ratio to Non-Oil and Gas GRDP is one of the indicators that make up the financial capacity factor in the assessment of technical requirements in the expansion of the regions by comparison of $0.12 \%$ percentage for new autonomous regions and $0.14 \%$ for Central Java districts.

Social Politics: The ratio of the population who participate in legislative elections that have the right to vote is one of the indicators that make up the socio-political factors in the assessment of technical requirements in the expansion of regions with a comparison of $0.66 \%$ percentage for the new autonomous regions and $0.75 \%$ for the districts of Central Java. As well as the number of community organizations is one of the indicators that make up the socio-political factors in the assessment of technical requirements in the expansion of regions with a comparison of $15.0 \%$ percentage for new autonomous regions and $18.57 \%$ for districts throughout Central Java.

Area Size: size of an area becomes one of the important indicators in the process of regional expansion. Brebes district is a very large area compared to districts/cities in Central Java. Coverage of such a vast area will certainly complicate the quality of public services which are hope to be effective, efficient, fast and accurate. Based on the consideration of this area, Brebes Regency is declared to be expanded so that the reach and distribution of services can be really felt by the people in the southern part of Brebes Regency. In the defense and security factor, there is only 1 indicator used, which is the ratio of the number of security personnel to the population. The results of quantitative data analysis showed that the new autonomous regions have a ratio of the number of security personnel to the population of $2.39 \%$, while the average district of Central Java is 10 with a percentage of $23.9 \%$. The 


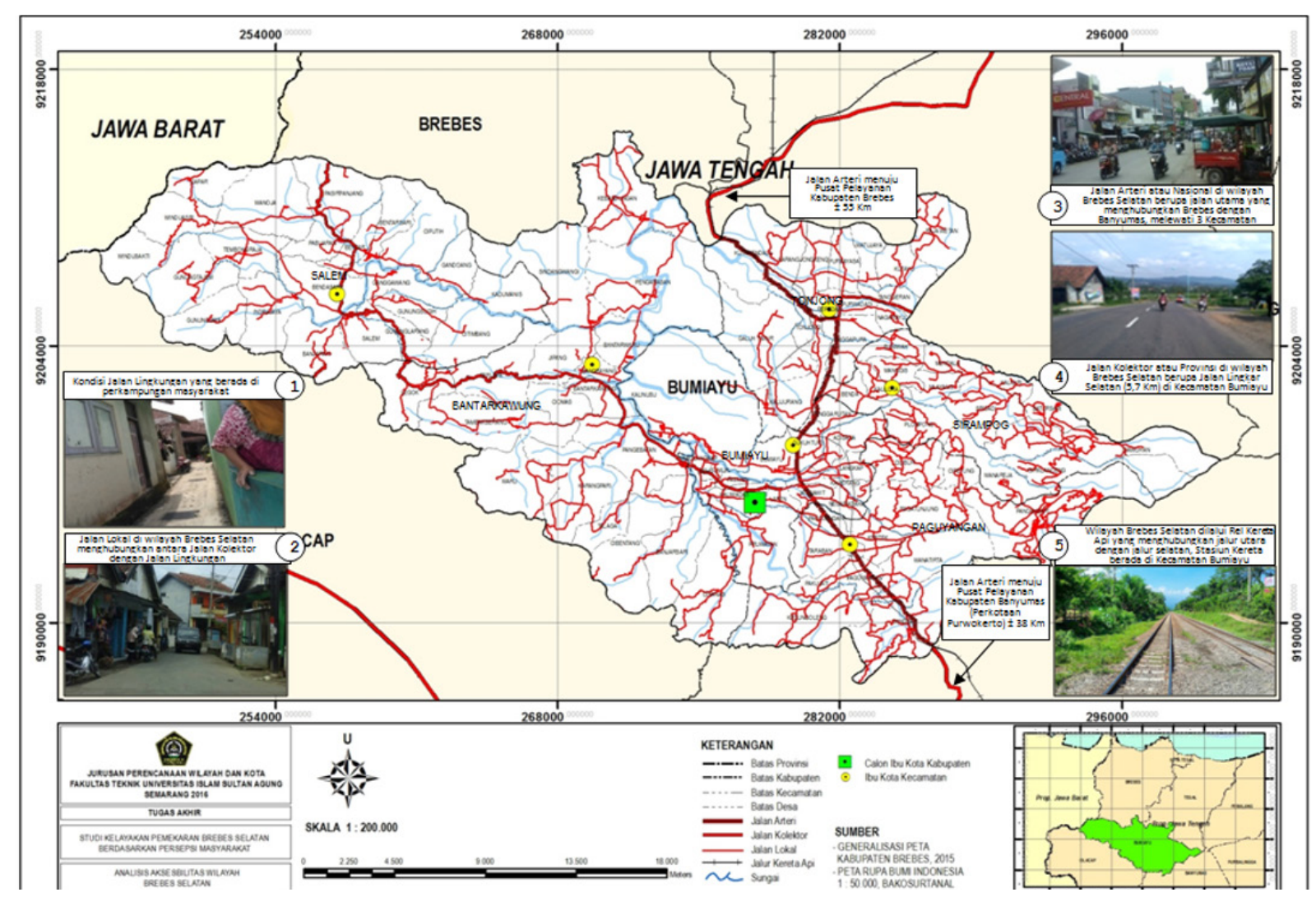

Source: RTRW Kabupaten Brebes 2011-2030 and Analysis Result 2017

Map 4. Analysis of South Brebes Accessibility

level of community welfare in general is a reflection of the level of education, health and community income as a basic need. The average HDI in Central Java is $72.18 \%$, while in Brebes Regency is $69.37 \%$ (Badan Pusat Statistik/Central Bureau of Statistics, 2016). Range of control related to governance which is a reflection of the proximity of location of capital candidates. Quantitative data states that the average mileage from prospective NAR to Brebes regency reaches 2.5 hours (Primary Survey, 2016)

\section{Feasibility Analysis of Physical Area Requirements}

The physical condition of the region is used to determine the scope of the expansion area and the location of the candidates of the capital through the scoring of 3 factors, namely the regional coverage, location of the capital candidates, as well as government facilities and infrastructures.

The scope of districts/municipality establishment is described in the district map of the candidate of regency/municipality in accordance with the regulation mandate. The coverage of new autonomous regions in Brebes Regency consists of 6 districts, namely: Bumiayu sub-district; Paguyangan sub-district; Bantarkawung sub-district; Salem sub-district; Sirampog sub-district; Tonjong Sub-district.

SWP South Brebes consists of 6 subdistricts, which has fulfilled the requirements of PP 78/2007 that states the scope of the newly created district is at least have five districts (Badan Pusat Statistik, 2016).

The location of the candidates for South Brebes capital is determined based on the decisions of the governor and the Regency and the Bupati/Regent. South Brebes capital city was determined after study of spatial factors, availability of facilities, accessibility, geographical condition, demography, socioeconomic, socio-cultural, and socio-politics. The district capitals to be chosen are those who are able to provide services. Good and optimal service can be realized by the availability of adequate supporting facilities and infrastructure. From these two alternatives, Bumiayu Sub-district has a better level of infrastructure and facilities compared to Bantarkawung Sub-district. This can be seen from the score of regional potentials that describes the higher service capacity of Bantarkawung sub-district. Bumiayu Sub-district has the highest score 
as the candidate for the capital city, which is 90 . While Bantarkawung is under with the score count of 90 .

Government facilities and infrastructure as a condition of regional expansion consists of buildings and land for local head offices, parliamentary offices, and local office units used to provide services to the community. The placement of the capital's location which was based on the analysis of the study of Brebes Regency Secretariat located in Bumiayu Sub-district, requires that selection of the location should be in an area with sufficient land availability of approximately 70 hectares. The center of the city that has been the center of trade and services remains allowed, while for the new capital which is intended to be the placement of government functions can be directed to vacant land, that available enough for government offices.

\section{Analysis of Public Perceptions on Readiness of Brebes Expansion}

Parameter of Attention, based on theoretical studies, refers to the condition of the individual's focus on receiving stimuli from the object or event experienced, in this case is Brebes Regency expansion. 79\% of respondents know the plan of regional expansion that occurred in Brebes Regency. The most responses related to community knowledge of regional expansion plans are very strongly agreed classification. This shows that the community agrees if the expansion is already known by most of people residing in South Brebes with the capital city in Bumiayu sub-district, as submitted by the Head of Tonjong Sub-district through interview:

\begin{abstract}
"Many people already know about the expansion, but not all understand the concept. They just know South Brebes will become a new district. They know the plan of expansion from the mass media and socialization from local government" (R3W8).
\end{abstract}

While $77 \%$ of respondents agree that the source of information they can relate to the expansion of the region is from the mass media. As for the socialization from Brebes Regency Government, 55\% of people stated quite agree. Referring to interview of respondent's answer (R3W7):

\footnotetext{
"People are involved in the socialization
} of regional expansion. Socialization is done by the community at village level, while Brebes Government is less facilitate"(R3W7)

The parameter of Experience, based on the study of theories refers to the conditions of individuals who feel or directly involved in events that occur, in this case is Brebes Regency expansion. $59 \%$ of respondents stated quite agree the Brebes Regency Government had held a socialization to introduce the process of expansion of territory to the community. As stated by respondents (R3W7) that the local government is lack of facilitating a socialization related to the expansion plan of the region. Socialization is most often done by village community groups. The people of South Brebes are only limited to knowing the existence of regional expansion plans, the local government is not facilitating well in the field through formal socialization. Only the village groups that routinely held socialization to the community. The result of socialization has no enough impact since it is not directly witnessed by the District Government. It also affects the participation of the community in every socialization held. $50 \%$ of respondents stated quite agree to have participated in the socialization of regional expansion plans. This shows that the interest of the community to participate in the process of regional expansion plan is still low. Head of Bumiayu Sub-district also conveyed the same thing through interview:

"The spirit of people for the regional expansion is very high, but at the time socialization in community is rarely interested to follow. Whereas the committee who held the socialization has invited the local community to join" (R4W7).

Community participation in the socialization process can be used as a means to deliver aspirations. Communities can communicate their needs regarding public services and other public facilities. Some people who have participated in the socialization process related to the expansion of Brebes Regency convey their aspirations in 2 ways, namely voting and discussion. $39 \%$ of respondents stated that they did not agree on the submission of their aspirations through voting and $59 \%$ of respondents stated that they agree that the delivery of aspirations is done through discussion. As informed by the interviewee:

"The people who participate in our 
socialization activities invite a joint discussion to introduce more regional expansion plans. The community can also convey ideas for expansion to be in accordance with their wishes"(R4W8)

Parameter Mindset, based on the study of theory refers to conditions that may affect the activity or individual characteristics related to events that occur, in this case is Brebes Regency expansion. $89 \%$ of respondents stated strongly agree. During this time people have difficulty when accessing public services located in the Regency Capital of Brebes. One of the difficulties faced by South Brebes people if they want to access service in the Regency Capital is the distance. Head of Bumiayu Sub-district also conveyed the same thing through interview:

"One of the reasons for the expansion of the region is the distance between South Brebes and Regency Capital located in North Brebes. The community here feels the difficulties if they have to go back and forth to do their necessities, usually administrative or government services"(R4W1)

There are 3 types of public services most often accessed by people of South Brebes in Regency Capital, namely jobs, shopping, and government services. $64 \%$ of respondents stated agree that they often access public service in the form of work to the Regency Capital, followed by $60 \%$ of respondents stated quite often agree to access public services in the form of government services, and only $27 \%$ of respondents who choose shopping service. South Brebes people prefer to meet the needs of shopping in Purwokerto, because the distance from South Brebes to Purwokerto closer than the distance to the Brebes Regency Capital as described by respondents through interviews:

"The difficulty of accessing services located in the Regency Capital becomes one of the backgrounds of expansion. South Brebes people prefer to go to Purwokerto to buy their needs, but for government services they will have to go to the capital located far away in North Brebes,"(R4W1)

The most common type of public service accessed by the people of South Brebes is work. There are 2 choices of answers for the frequency to the Regency Capital, which is every day and every week. $51 \%$ of respondents stated quite agree to choose the frequency of time each week to the go to Regency Capital, and 29\% of respondents said less agree to choose the frequency of time every day to get to the Brebes Regency Capital.

Parameter Needs based on the study of theory refers to the needs, motivation, or individual expectations of the object or event experienced, in this case is the expansion of Brebes Regency. 94\% of respondents stated strongly agreed to support the continuation of the process of Brebes Regency expansion planning. No respondent chooses a classification of disagreement or disapproval of the expansion process. Based on frequency, 72 respondents voted strongly agree, 27 respondents chose the agree, and only 1 person who takes quite agree. It shows that the desire of South Brebes people to do the expansion is very strong. If South Brebes has officially become a NAR, people have hope in terms of improving public services and public facilities. $86 \%$ of respondents stated strongly agree to improve public services first on NAR, followed by increasing public facilities because $75 \%$ of respondents agreed. The community hopes that with the formation of South Brebes NAR later, it can address the public's difficulties in accessing public services.

\section{Analysis of Preparation Plan for the Brebes Regency Expansion}

Community leaders is a mobilizer or represent the local community to convey ideas related to the desire of regional expansion. $80 \%$ of respondents agreed that community leaders are the originators of the expansion of Brebes Regency. Community leaders are considered to have an important role to mobilize other communities in formulating the sustainability of regional expansion plans in Brebes Regency, as submitted by respondents through interviews:

"Community leaders became one of the initiators of regional expansion in Brebes Regency. They came from local community and were not part of the local government. The role of community leaders mobilizes other communities through village groups to discuss the sustainability of regional expansion" (R3W2).

Based on frequency, 41 respondents voted strongly agree and 33 respondents voted in favor. The remaining 18 respondents chose quite agree, 7 respondents chose less agree, and 1 respondent chose not agree. 
It indicates that the role of the community has an impact in the process of expansion of South Brebes.

\section{Drivers of Regional Expansion}

There are four factors that drive regional expansion in Brebes Regency, namely accessibility, public facilities, employment opportunities, and politics. $79 \%$ of respondents agreed to public facilities as the main drivers of regional expansion. Society assesses that in South Brebes the availability of public facilities is still limited compared to North Brebes as the Regency Capital. Furthermore, $78 \%$ of respondents stated that accessibility agreed to be a factor for the expansion of the region. The topographical condition of the predominantly hilly of South Brebes region makes it difficult for some people to access their needs in the regency capital which has coastal topography since it requires long distances and more expenses. The third factor is the employment, $58 \%$ of respondents stated quite agree. While the political party was ranked fourth as the trigger factor of the expansion of the region with $32 \%$ of respondents said less agree.

\section{Problems Accessing Public Service}

The availability of public facilities became the first choice of South Brebes community as a trigger factor for the expansion of the region. This shows that the availability of public facilities in South Brebes region is still limited when compared to North Brebes as the Regency Capital. In accessing public services, the public cannot be separated from the problems, which are related to accessibility, transportation, and costs. $79 \%$ of respondents stated agreed that accessibility as the main problem that must be faced when accessing public services in the Regency Capital. Remote access and poor road conditions make people choose accessibility as the main problem. Furthermore, $73 \%$ of respondents agreed that the cost becomes a problem when accessing public services in Regency Capital. The last problem according to the people of South Brebes is transportation, that is as much as $68 \%$ of respondents agreed.

\section{Conclusion}

The people of South Brebes showed good attention and responses to the process of regional expansion, one of them by appointing community leaders who are considered to represent and mobilize local people to convey ideas related to the desire of regional expansion. The Local Government of Brebes Regency introduced the plan of expansion of the region to the people of South Brebes through socialization in community discussions. The hope of South Brebes people to the planning process of the regional expansion is very high and hoped that the Local Government can continue the expansion plan, so that it is no longer become a regional expansion seasonal issue.

The driving factors of the expansion process include the construction of the availability of public facilities, employment opportunities and the opening of transportation lines that connect accessibility to the predominantly hilly South Brebes region which makes it difficult for some people to access their needs in the capital of the Regency located on the coastal topography, that requiring long distances and more cost.

\section{References}

Badan Pusat Statisitik, (2016). Kabupaten Brebes dalam Angka 2016. Pemda Brebes.

BAPPEDA. (2011). Rencana Tata Ruang Wilayah (RTRW) Kabupaten Brebes 20112030. Pemda Kabupaten Brebes.

Muhadjir, Noeng. (1991). Metodologi Penelitian Kualitatif. Jakarta : Rake Sarasin.

Nazir, Mohammad. (1999). Metode Penelitian. Jakarta: Ghalia Indonesia.

Pemerintah Kabupaten Brebes. (2015). "Kajian Rencana Pemekaran Wilayah Kabupaten Brebes." Studi Sektretaris Daerah Kabupaten Brebes.

Rakhmat, Jallaludin. (1990). Psikologi Komunikasi. Bandung: Remaja Karya.

Semiawan, Conny R. (2010). Metode Penelitian Kualitatif: Jenis, Karakteristik, dan Keunggulan. Jakarta: PT Grasindo.

Setyawan Salam, Dharma. (2004). Otonomi Daerah Dalam Perspektif Lingkungan, Nilai dan Sumber Daya. Cetakan Dua. Bandung: Djambatan.

Silitonga, Benget. (2000). Kratos Minus Demos: Demokrasi Indonesia, Catatan dari Bawah. Medan: Perhimpunan Bantuan Hukum dan Advokasi Rakyat Sumatera Utara (BAKUMSU).

Sjafrizal. (2008). Ekonomi Regional: Teori dan Aplikasi. Jakarta: Niaga Swadaya.

Sudjana, Nana. (2009). Penilaian Hasil Proses Belajar Mengajar. Bandung: PT Remaja 
Rosdakarya.

Surkati, Achmad, (2012). Otonomi Daerah sebagai Instrumen Pertumbuhan Kesejahteraan dan Peningkatan Kerjasama Antardaerah. MIMBAR, Vol. XXVIII, No. 1 (Juni, 2012): 39-46 'Terakreditasi' SK Dikti No. 64a/DIKTI/Kep/2010 39

Sunaryo. (2004). Psikologi untuk Keperawatan. Jakarta: Penerbit Buku Kedokteran EGC.

Supratman, Lucy Pujasari dan Adi Bayu Mahadian. (2016). Psikologi Komunikasi. Yogyakarta: CV Budi Utama.

Syarbaini, Syahrial. (2014). Pendidikan
Kewarganegaraan untuk Perguruan Tinggi. Bogor: Ghalia Indonesia.

Tirtosudarmo, Riwanto. (2007). Mencari Indonesia: Demografi-Politik Pasca -Soeharto. Jakarta: Lembaga IImu Pengetahuan Indonesia (LIPI).

Yana Tatiana, Muhammad Firdaus, dkk. (2015). Analisis Perwilayahan Pembangunan dan Iklim Investasi di Provinsi Bengkulu. MIMBARVol. 31, No. 2 (Desember, 2015):295-306'Terakreditasi' SK Kemendikbud, No.040/P/2014, berlaku 18-02-2014 s.d18-02-2019 